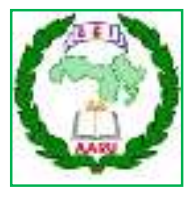

Arab Univ. J. Agric. Sci., Ain Shams Univ., Cairo, Egypt 28(2), 625-638, 2020

Website: http://ajs.journals.ekb.eq

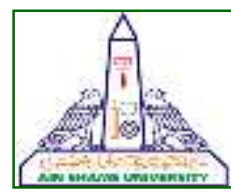

625

\title{
EFFECT OF SUBSTITUTING ALFALFA HAY WITH GRADED LEVELS OF FENNEL AND BASIL STRAWS IN GROWING RABBIT DICTS
}

\author{
Hayam E. Deraz ${ }^{1^{*}}$, Abdel-Azeem ${ }^{2}$ F., El-Behairy ${ }^{3}$ U.A., \\ Thanaa F. Mohammadi ${ }^{1}$ and El-Bordeny ${ }^{4} \mathrm{~N}$.
}

1- Regional Center for Food and Feed, Agric. Res. Center, Giza, Egypt

2- Poultry Production Dept., Fac. of Agric., Ain Shams Univ., P.O. Box 68, Hadayek Shoubra 11241, Cairo, Egypt

3- Horticulture Dept., Fac. of Agric., Ain Shams Univ., P.O. Box 68, Hadayek Shoubra 11241, Cairo, Egypt

4- Animal Production Dept., Fac. of Agric., Ain Shams Univ., P.O. Box 68, Hadayek Shoubra 11241, Cairo, Egypt

*Corresponding author: hayamderaz@yahoo.com

Received 1 March, 2020

Accepted 28 June, 2020

\section{ABSTRACT}

The aim of this study was to investigate the ef fect of replacing alfalfa hay with graded levels of fennel and basil straws in the diets of growing rabbits aged from 5 to 11 weeks. Eighty-four unsexed, weaned New Zealand white rabbits, aged 5 weeks, were randomly assigned to seven dietary treatments (12 rabbits/treatment): A control diet; three diets the basil hay substituted for $25 \%, 50 \%$ and $75 \%$ of alfalfa straw; and three diets the fennel hay replaced $25 \%, 50 \%$ and $75 \%$ of alfalfa straw. Results obtained showed that replacement of alfalfa hay with $25 \%$ fennel straw significantly reduced average daily gain compared with the other experimental treatments, while no significant difference was observed among the other experimental treatments during the stage 5-8 week. On the contrary, the animals fed diets contained $25 \%$ fennel straw gave significantly higher average body weight gain compared with the other experimental groups and no significant differences were observed among the other experimental treatments during 8-11 weeks. Regarding body weight gain during the total period from 5 to 11 weeks of age, the result indicates that no significant differences among all treatments were detected. The values of FCR showed no significant differences within all tested groups. Rabbits group fed $\mathrm{B} 50 \%$ recorded the highest significant digestibility coefficients of dry matter, organic matter, crude protein, ether extract, neutral detergent fiber, acid detergent fiber, TDN and DCP when compared to all groups. Levels of basil straw and fennel straw in rabbit diets induced an insignificant effect on hemicellulose. There were higher dressing and hot carcass percentages were recorded with rabbits fed B50\%. Plasma values of total protein, albumin, globulin, cholesterol or Alanine aminotransferase (ALT) and Aspartate aminotransferase (AST) concentration were not significantly affected due to adding basil straw and fennel straw to rabbit diets. Replacement alfalfa hay with fennel and basil straw resulted in decrease feed cost. Rabbits fed B25\% showed higher economic efficiency percentage compared to the other treatments. The results revealed that using basil straw and fennel straw at $25 \%$ in growing NZW rabbit diets had no detrimental effects on productive performance, the physiological and biochemical status and it could be used economically instead of alfalfa hay.

Keywords: Fennel straw, Basil straw, Rabbit, Performance, Carcass traits, Economic efficiency

\section{INTRODUCTION}

The high cost of concentrate feed mixtures and alfalfa hays and unavailability of fresh Egyptian berseem (Trifolium alexandrinum) during the summer season are the major problems confronting the development of livestock. Therefore, it is believed that the inclusion of some agricultural by-products to replace a part of a conventional diet for animals has become an obligation (El-Tahan et al 2003). Also 
using fennel hay in rabbit diets can be one of the alternative solutions to environmental problems in some regions as an Al Fayoum, where the Agriculture Wests accumulated and caused many environmental hazards.

Egypt likes other developing countries suffering from a deficiency in animal protein sources. So, emphasis should be placed on producing animals less competitive to man. The rabbit, being a non-ruminant herbivore, can efficiently utilize different sources of roughage and convert them into highquality animal protein for human consumption.

Medicinal and aromatic plants are cultivated in large areas in Egypt about 48 thousand feddans were cultivated with medicinal and aromatic plants in Egypt (Agriculture Economic, 2005). Fennel (Foeniculum volgare Mill) is cultivated in 2207 feddans and produced 3394 tons seeds and an average of 15-18 tons of green forages/feddan (AboZeid, 1988). Basil (Ocimum basilicum) cultivated mainly to produce dry leaves and seeds in about 5300 feddan to yield about 13500 ton and 159000 tons of wastes (Agriculture Economic, 2005). Recently, Radwan and Khalil (2002) and Abo Sekken et al (2008) suggested that fennel hay (FNH) could be used in the rabbit diet up to $50 \%$ without any adverse effects on the performance of growing rabbits. Finally, Abdel-Azeem et al (2010) revealed that using fennel hay at a level $10.6 \%$ in growing NZW rabbit diets had no deleterious effects on physiological and biochemical status and it could be used economically instead of $33.33 \%$ clover hay in growing rabbit diets.

The aim of this study, therefore, was to evaluate effect of replacement of alfalfa hay with ascending levels of fennel hay and basil hay in rabbit diets on its productive performance.

\section{MATERIALS AND METHODS}

The present experiment was carried out at Rabbit Experimental Station, Faculty of Agriculture, Cairo University, Giza, the Labs of Regional Center for Food and Feed and Labs of Animal Nutrition, Faculty of Agriculture, Ain Shams University.

Experimental materials: The crop residuals of Foeniculum vulgar and Ocimum basilicum were used in this study. So we called them Fennel straw and Basil straw the materials were collected after harvesting the seeds and the straw were shopped before using in the diets
The fennel and basil straw were obtained from the private farm belonging to El- Qaliubiya governorate. The chemical compositions of both by-products in comparison with alfalfa hay are presented in Table (1).

\section{Experimental animals and diets}

A total number of 84 unsexed, weaned New Zealand White (NZW) rabbits of 5 weeks old were randomly divided into seven equal groups, with four replicates of 3 rabbits with an average initial body weight of $625.42 \pm 18.25$ were used. The rabbits were assigned randomly to 28 experimental replicates.

Seven pelleted experimental diets were formulated to be approximately isocaloric, isonitrogenous and iso-fibrous. All experimental diets were formulated and pelletized at commercial feed planet belong to Egyptian Canadian (EGYCAN) Company to meet the recommended nutrient requirements of rabbits according to NRC (1977) and Cheeke (1987), but with replacement of alfalfa hay with 0 , 25,50 and $75 \%$ of fennel or basil by-products. The experimental diets were formulated to contain 16.84 to $16.97 \%$ crude protein and 2502 to $2555 \mathrm{DE}$ $\mathrm{kcal} / \mathrm{kg}$. The formula and chemical composition of the experimental diets are shown in Tables 2 and 3.

\section{Animals management}

The experimental rabbits were housed in metal battery cages (measuring $45 \mathrm{~cm} \times 54 \mathrm{~cm} \times 35 \mathrm{~cm}$, four cages, each battery) supplied with separated feeders and automatic nipple drinkers. The experimental diets and clean water were offered daily, adlibitum, throughout the experimental period $(6$ weeks). Rabbits in all treatments were kept under similar conditions of management. Individual live body weight and feed consumption were recorded at weekly intervals during the experimental period (5-11 weeks of age).

\section{Digestion trial}

Digestion trials were conducted at the end of growth trial to determine the digestibility values and nutritive value of the experimental diets expressed as total digestible nutrients (TDN, \%), digestible energy (DE, Kcal/Kg feed) and digestible crude protein (DCP, \%). Four animals representing each group were individually housed in metabolic cages equipped with a stainless-steel screen and $4 \mathrm{~mm}$ mesh to retain feces but allow free passage of urine. Feed and water intake were offered to rabbits ad- 
libitum during the digestion trial. The digestion trial lasted for 10 days as preliminary period while the collection period lasted for 5 days in which feces was collected daily before the morning meal, weighed fresh and sprayed with $2 \%$ boric acid for trapping any ammonia released from feces and dried at $60{ }^{\circ} \mathrm{C}$ for $24 \mathrm{hrs}$ in an air drying oven. The feces were then ground, mixed, and stored for subsequent chemical analysis. Samples of diets and feces were chemically analyzed to determine the digestibility coefficients and nutritive values of the experimental diets. The digestible energy (DE) of the experimental diets was calculated according to Fekete and Gippert (1986) by applying the equation:

$\mathrm{DE}(\mathrm{kcal} / \mathrm{kg})=4253-32.6(\mathrm{CF} \%)-144.4$ (total ash\%).

\section{Analytical methods}

The proximate chemical analysis of experimental diets and dried feces samples for dry matter (DM), organic matter (OM), crude protein (CP), ether extract $(E E)$, and ash was carried out according to the Association of Official Analytical Chemists (A.O.A.C. 2002). Nitrogen free extract (NFE) of both feed and feces was determined by difference. Neutral detergent fiber (NDF), acid detergent fiber $(A D F)$, and acid detergent lignin (ADL) were analyzed according to Van-Soest et al (1991). Cellulose, hemicellulose and lignin were calculated according the following equation:

Cellulose $=$ ADF - ADL Hemicellulose $=$ NDF - ADF .

The total digestible nutrients (TDN) were calculated according to the classic formula (Cheeke et al 1982). $\%$ TDN $=\%$ DCP $+\%$ DCF + \%DNFE + $(2.25 x$ $\%$ DEE).

\section{Blood sampling and analysis}

Blood samples were collected at slaughtering in heparinized glass tubes (6 samples per each treatment group). Blood plasma was separated by centrifugation at $4000 \mathrm{rpm}$ for 15 minutes. The collected plasma was stored at $-20^{\circ} \mathrm{C}$ until analysis. Total protein of blood plasma was determined as described by Armstrong and Carr. (1964). Albumin was determined as described by Doumas et al (1971). Globulin was calculated by difference. A: G ratio was calculated by dividing the value of albumin on the value of globulinClolesterol according to Pisani et al (1995). Triglycerides according to Greiling and Gressner (1995). Urea was determined using
Berthelot method according to Fawcett and Soctt (1960). Creatinine was determined by the method of Husdan (1968). ALT and AST were determined by the method of Reitman and Frankel (1957). Cholesterol in blood plasma was measured by quantitative enzymatic colorimetric determination according to Stein (1986).

Cholesterol, triglycerides and urea are mentioned in Table 6 but not in methodology, please add them here. Add the source of kits, and system you have used for analysis (spectro or elisa version, and company).

\section{Slaughter trial}

At the end of the experimental period, four rabbits were selected from each treatment for slaughter test. The assigned rabbits were fasted for about 12 hours, after which they individually weighed and slaughtered to complete bleeding. The slaughter weight of each rabbit was recorded, and the skin was immediately loosened and removed. Liver, kidney, heart, head and the rest of the body were weighed to determine carcass weight dressing weight, total edible parts and non-edible parts. All records were related to the live body weight of the animal.

\section{Caecum characteristics}

After slaughtering, gastrointestinal tracts were individually removed from four rabbits from each group, the caecum was weighted and the $\mathrm{pH}$ value of the caecal content was measured using $\mathrm{pH}$-meter.

\section{Economic evaluation}

The economic efficiency (EEF) was calculated according to the following equation: $E E F=A-B / B \times$ 100. Where $A$ is selling price of obtained gain (LE) and $B$ is the feeding cost of this gain. The performance index $(\mathrm{PI})$ was calculated according to the equation described by North (1981) by applying the equation:

$\mathrm{PI}=$ Live body weight $(\mathrm{Kg}) /$ Feed conversion $\times 100$

\section{Statistical analysis}

Data collected in this study were statistically analyzed using the general liner models (GLM) of (SAS, 2002). One-way model was used to study the 
effect of treatment on different parameters, the used model was as follows:

$$
Y_{i j} \quad=\mu+T i+e_{i j}
$$

Where:

$Y_{i j}=$ The observation on the $I^{\text {th }}$ treatment, $\mu=$ Overall mean

$\mathrm{Ti}=$ Effect of the 1 th treatment and eij $=$ Random error treatment.

Duncan's Multiple Range test (Duncan, 1955) was also used for the comparison among means of the experimental groups.

\section{RESULTS AND DISCUSSION}

\section{Chemical composition of basil straw, fennel} straw and alfalfa hay (\% on DM basis)

The data of Table (1) showed that the alfalfa hay had relatively higher OM, CP, EE, DE than those in basil straw and fennel straw. On the contrary, the fennel straw had higher CF while, DM, OM, Ash content is close in the two fiber sources (basil straw and Fennel straw). Thus, that the fennel straw had higher NDF, ADF while basil straw had lower ADL than alfalfa hay and fennel straw. The same trend was obtained by Ibrahim (2000) who observed that DM in fennel straw was (92\%) and ADL (14.18\%). On the other hand, Abdel-Azeem et al (2010) found that the chemical composition of fennel hay contains 87.6, 11.6, 1.03, 13.5, 32.97 and 1375 for DM, $\mathrm{CP}, \mathrm{EE}$, Ash, NFE and DE (Kcal/kg).

\section{Effect of replacement alfalfa hay with ascend-} ing levels of basil and Fennel straws in rabbit diets on ration formulation and its chemical analysis

The data of Table (2) showed that the different ingredients especially yellow corn, soybean meal, and wheat bran were used at different ratios to formulate the experimental diets to be approximately iso- caloric, iso-nitrogenous and iso-fibrous as possible. Additionally, they, approximately, contained similar levels of calcium, phosphorus, methionine + cysteine, and lysine.

Moreover, the data showed that the replacement of alfalfa hay with ascending level of basil and fennel straw resulted in gradually increased soybean meal $\%$ parallel to gradually decrease in wheat bran $\%$. These actions have been done to get ap- proximately isocaloric and iso-nitrogenous experimental diets. The previous data revealed theoretically that, it is possible to use basil straw and fennel straw as replacer to alfalfa hay with some modification in diet formula.

Table 1. Chemical composition of basil straw, fennel straw, and alfalfa hay meal (\% on DM basis)

\begin{tabular}{|l|l|l|l|}
\hline \multicolumn{1}{|c|}{ Items } & $\begin{array}{c}\text { Basil } \\
\text { straw }\end{array}$ & $\begin{array}{c}\text { Fennel } \\
\text { straw }\end{array}$ & $\begin{array}{c}\text { Alfalfa } \\
\text { hay }\end{array}$ \\
\hline Dry matter & 92.25 & 92.42 & 88.95 \\
Organic matter & 80.41 & 80.71 & 87.87 \\
Crude protein & 11.23 & 7.00 & 20.85 \\
Crude fiber & 27.00 & 37.13 & 30.88 \\
Ether extract & 1.04 & 0.71 & 2.84 \\
Ash & 19.29 & 15.51 & 12.13 \\
Nitrogen free extract & 41.44 & 39.65 & 42.85 \\
Neutral detergent fiber & 40.43 & 59.54 & 46.06 \\
Acid detergent fiber & 37.5 & 50.31 & 35.97 \\
Acid detergent Lignin & 9.20 & 14.92 & 41.60 \\
Hemicellulose & 2.96 & 9.24 & 10.10 \\
Cellulose & 28.2 & 35.39 & 31.81 \\
Lignin & 7.95 & 11.93 & 8.20 \\
Calcium(mg/kg) & 5.018 & 3.035 & 3.07 \\
Phosphors(mg/kg) & 18.32 & 23.5 & 0.03 \\
Digestible energy (Kcal/gm) & 587.324 & 257.08 & 1494.74 \\
\hline
\end{tabular}

The digestible energy (DE) was calculated according to Fekete and Gippert (1986) by applying the equation:-

DE $(\mathrm{kcal} / \mathrm{kg})=4253-32.6(\mathrm{CF} \%)-144.4$ (total ash\%).

The data of Table (3) showed that the control diet (Con0) showed the highest numerical values of CF, ADF and ADL contents, and the lowest value of EE contents. On the other hand, diet contained basil straw with $75 \%$ replacement level instead of alfalfa hay (B75) was numerically highest EE content, and lowest CP and DE contents, Furthermore, diet contained fennel straw with $75 \%$ replacement level (F75) was the highest CP component. Moreover, diet contained fennel straw 50\% (F50) was the highest DE content. And, fennel straw diet (F25) was the lowest in CF component and by fiber fraction analysis the results concluded that: Control diet (Con0) was the highest ADF and ADL contents. Moreover, B75 treatment was the highest NDF content whileF25 treatment was the lowest ADF and ADL contents. 

straws in growing rabbit dicts

Table 2. Formulation of experimental diets

\begin{tabular}{|l|c|c|c|c|c|c|c|}
\hline \multirow{2}{*}{\multicolumn{1}{|c|}{ Ingredients }} & \multicolumn{7}{|c|}{ Replacement level } \\
\cline { 2 - 8 } & \multicolumn{3}{|c|}{ Basil straw } & \multicolumn{3}{c|}{ Fennel straw } \\
\cline { 2 - 8 } & (Con0) & (B25) & (B50) & (B75) & (F25) & (F50) & (F75) \\
\hline Barley grains & 20 & 20 & 20 & 20 & 20 & 20 & 20 \\
Yellow corn & 10 & 10 & 10 & 10 & 10 & 10 & 10 \\
Soybean meal & 17.35 & 17.95 & 18.55 & 20.38 & 17.95 & 18.55 & 20.38 \\
Wheat bran & 20 & 19.5 & 19 & 17.6 & 19.5 & 19 & 17.6 \\
Alfalfa hay & 30 & 22.5 & 15 & 7.5 & 22.5 & 15 & 7.5 \\
Basil straw & 0.00 & 7.5 & 15 & 22.5 & 0.00 & 0.00 & 0.00 \\
Fennel straw & 0.00 & 0.00 & 0.00 & 0.00 & 7.5 & 15 & 22.5 \\
Vegetable oil & 0.3 & 0.3 & 0.3 & 0.2 & 0.3 & 0.3 & 0.2 \\
Limestone & 0.7 & 0.6 & 0.5 & 0.3 & 0.6 & 0.5 & 0.3 \\
Salt (Nacl) & 0.4 & 0.4 & 0.4 & 0.2 & 0.4 & 0.4 & 0.2 \\
Methionine & 0.1 & 0.1 & 0.1 & 0.17 & 0.1 & 0.1 & 0.17 \\
Premix & 0.3 & 0.3 & 0.3 & 0.3 & 0.3 & 0.3 & 0.3 \\
Calcium phosphate, dibasic & 0.85 & 0.85 & 0.85 & 0.85 & 0.85 & 0.85 & 0.85 \\
Total & 100 & 100 & 100 & 100 & 100 & 100 & 100 \\
Price/ton & 5170 & 5090 & 4990 & 4860 & 5070 & 5000 & 4870 \\
\hline
\end{tabular}

*Each Kilogram of premix contains: $2000.000 \mathrm{IU}$ vit. $\mathrm{A}, 150.000 \mathrm{IU}$ vit. D, $8.33 \mathrm{~g}$ vit. $\mathrm{E}, 0.33 \mathrm{~g}$ vit $\mathrm{K}, 0.33 \mathrm{~g}$ vit. $\mathrm{B} 1,1.0 \mathrm{~g}$ vit. B2, $0.33 \mathrm{~g}$ vit. B6, $8.33 \mathrm{~g}$ vit. B5, $1.7 \mathrm{mg}$ vit. B12, 3.33g Pantothenic acid, 33mg Biotin, $0.83 \mathrm{~g}$ Folic acid, $200 \mathrm{~g}$ Choline chloride, 11.7g Zn, 12.5g Fe, $16.6 \mathrm{mg} \mathrm{Se}, 16.6 \mathrm{mg} \mathrm{Co}, 66.7 \mathrm{~g} \mathrm{Mg}$ and $5 \mathrm{~g} \mathrm{Mn}$.

Table 2. Formulation of experimental diets

\begin{tabular}{|l|c|r|r|r|r|r|r|}
\hline \multirow{2}{*}{ Items } & \multicolumn{7}{c|}{ Replacement level } \\
\cline { 2 - 7 } & \multirow{2}{*}{ (Con0) } & \multicolumn{3}{c|}{ Basil straw } & \multicolumn{3}{c|}{ Fennel straw } \\
\cline { 2 - 8 } & & $\mathbf{( B 2 5 )}$ & $\mathbf{( B 5 0 )}$ & $\mathbf{( B 7 5 )}$ & $\mathbf{( F 2 5 )}$ & $\mathbf{( F 5 0 )}$ & $\mathbf{( F 7 5 )}$ \\
\hline Dry matter & 91.56 & 92.48 & 92.25 & 92.18 & 92.35 & 92.37 & 91.41 \\
Organic matter & 92.5 & 92.5 & 92.19 & 91.65 & 91.77 & 91.87 & 91.39 \\
Crude protein & 16.96 & 16.93 & 16.92 & 16.84 & 16.94 & 16.97 & 16.96 \\
Crude fiber & 13.39 & 12.60 & 12.40 & 12.04 & 12.96 & 13.00 & 13.02 \\
Ether extract & 2.66 & 3.26 & 3.12 & 3.57 & 3.01 & 2.84 & 3.19 \\
Ash & 7.5 & 7.5 & 7.81 & 8.35 & 8.23 & 8.13 & 8.61 \\
Silica & 1.26 & 1.31 & 1.19 & 1.58 & 1.46 & 1.88 & 1.64 \\
Nitrogen free extract & 59.49 & 59.71 & 59.75 & 59.20 & 58.86 & 59.06 & 58.22 \\
Neutral detergent fiber & 26.62 & 24.8 & 25.27 & 26.81 & 23.6 & 24.76 & 26.76 \\
Acid detergent fiber & 18.72 & 16.35 & 17.06 & 18.19 & 18.3 & 16.55 & 17.99 \\
Acid detergent Lignin & 5.01 & 4.63 & 4.09 & 4.66 & 3.58 & 4.24 & 4.56 \\
Hemicellulose & 7.87 & 8.45 & 8.21 & 8.62 & 5.34 & 8.21 & 8.77 \\
cellulose & 13.74 & 11.72 & 12.97 & 13.53 & 14.76 & 12.31 & 13.43 \\
Lignin & 4.09 & 3.7 & 2.94 & 3.78 & 2.46 & 2.93 & 3.32 \\
\hline Digestible energy (Kcal/kg) & $\mathbf{2 5 5 2}$ & $\mathbf{2 5 5 0}$ & $\mathbf{2 5 2 9}$ & $\mathbf{2 5 0 2}$ & $\mathbf{2 5 5 0}$ & $\mathbf{2 5 5 5}$ & $\mathbf{2 5 3 8}$ \\
\hline
\end{tabular}


3. Effect of basil straw and fennel straw inclusion in rabbit diets

\subsection{Feed consumption (g/rabbit/day)}

The data of daily feed consumption (DFC) presented in Table (4) showed that the group received F75 diets recorded numerically highest DFC, while the lowest DFC recorded for B50 treatment followed by $\mathrm{F} 50, \mathrm{~B} 75, \mathrm{~B} 25, \mathrm{~F} 25$, respectively compared to the control group (Con0) during 5 to 8 weeks. On another hand, the groups order changed in the following periods (From 8 to 11 Weeks).

The data of Table (4) clearly showed that rabbit groups received a $\mathrm{B} 75$ diet recorded the highest DFC during 8-11 weeks of age followed by F50, B50 while the lowest DFC was recorded for Con0 treatment. Moreover, during the entire experimental period (5-11 weeks of age), the data revealed that the average DFC of $B 75$ recorded the highest DFC followed by F25 and F75, compared to the control group (Con0), while the lowest DFC recorded for B25 followed by B50. These results may be attributed to that the different diets are approximately iso-caloric, iso-nitrogenous and iso-fibrous and contain a similar percentage of calcium, phosphorus, methionine + cysteine and lysine. These findings may be considered practical evidence that basil and fennel straw can be used as replacers to alfalfa hay as a source of fiber without any adverse effect on feed consumption. In this connection, AbdelAzeem et al (2010) found that fennel straw increase daily feed consumption when it is replaced for clover hay at rate up to $33 \%$. Also, they found that the mean feed consumption was low during the first period (6th and7th weeks of age) then increased during the following periods up to the last period $\left(9^{\text {th }}\right.$ and $11^{\text {th }}$ weeks of age). Rabbits, like most animals, adjust their voluntarily feed intake to meet their needs. In addition, all experimental diets have a similar percentage of methionine NRC (1977) however, Colin et al (1973) reported that the increase in methionine percentage causes a large decrease in feed intake.

The digestible energy (DE) was calculated according to Fekete and Gippert (1986) by applying the equation: DE $(\mathrm{kcal} / \mathrm{kg})=4253-32.6(\mathrm{CF} \%)$ 144.4 (total ash\%).

\subsection{Nutrients digestibility and nutritive values}

The data of nutrient digestibility coefficients and feeding values as total digestible nutrients (TDN) and digestible crude protein (DCP) are shown in Table (5). The data clearly indicated that replacing $(25,50$, and $75 \%)$ of alfalfa hay with basil straw caused a significant increase in DM, OM, CP, EE and NDF digestibility in comparison with the group fed the control diet (Con0). While the group fed B50 diet recorded significantly higher NFE digestibility compared to the group fed Con0 diet. Replacement alfalfa hay with fennel straw in rabbit diets at levels $(25,50$ and $75 \%)$ significantly $(p \leq 0.05)$ increased EE digestibility and significantly decreased NFC digestibility compared to control group (Con0) while no significant differences were observed between Fennel diets and control diet in NDF, hemicellulose and cellulose digestibility. The rabbit's group fed F50 diet recorded significantly lower ADF digestibility compared to control while the groups fed F25 and F75 diets not significantly affected. On another hand, the group fed F25 diet recorded significantly higher DM, OM and $\mathrm{CP}$ digestibility compared to control. While the groups fed F50 and F75 diets recorded lower DM digestibility as compared to control. Furthermore, no significant differences were observed among the different experimental treatments in TDN and DCP values, except the group, fed B50 diet recorded higher TDN and DCP values compared to the control group. Abdel-Azeem et al (2010) found that Rabbits group fed 31.6\% Fennel hay (As $50 \%$ of the components of the diet or $100 \%$ of alfalfa hay substitution) was significantly $(p<0.05)$ highest in EE digestibility than other groups. Moreover, Radwan and Khalil (2002) showed that the digestibility values of diets tend to improveas fennel straw levels increased and, the digestion coefficient of $E E$ and CF were significantly ( $p \leq 0.05)$ higher than those of clover hay, while digestibility coefficients for $\mathrm{OM}, \mathrm{CP}$, and NFE insignificantly differed. Treatments had no significant effect on CP and EE digestibility. On the other hand, dietary treatments improved both TDN and DCP values. Abou Sekken et al (2008) reported that digestibility coefficients values of $\mathrm{OM}, \mathrm{CP}, \mathrm{CF}$, and NFE did not differ significantly when rabbits fed on diets contained 18,36 or $54 \% \mathrm{FNH}$ and marjoram hay mixture. 
Table 4. Effect of replacing alfalfa hay with basil and fennel straw on daily feed consumption ( $\mathrm{g} / \mathrm{day})$ of growing rabbits

\begin{tabular}{|c|c|c|c|c|c|c|c|c|c|}
\hline \multirow{3}{*}{ Items } & \multicolumn{7}{|c|}{ Replacement level } & \multirow{3}{*}{ \pm SEM } & \multirow{3}{*}{ p-value } \\
\hline & \multirow{2}{*}{ Cono } & \multicolumn{3}{|c|}{ Basil straw } & \multicolumn{3}{|c|}{ Fennel straw } & & \\
\hline & & B25 & B50 & B75 & F25 & F50 & F75 & & \\
\hline \multicolumn{10}{|c|}{ Daily Feed consumption (DFC) from } \\
\hline 5 to 8 weeks & 70.09 & 66.36 & 56.67 & 65.95 & 69.43 & 57.60 & 73.33 & 8.27 & 0.95 \\
\hline 8 to 11 weeks & 115.15 & 108.57 & 120.24 & 129.63 & 119.97 & 126.53 & 115.48 & 2.70 & 0.82 \\
\hline 5 to 11 weeks & 92.62 & 87.46 & 88.45 & 97.79 & 94.70 & 92.06 & 94.40 & 1.37 & 0.79 \\
\hline
\end{tabular}

Mean within the same row with different superscripts are significantly different $(p \leq 0.05)$.

Table 5. Effect of replacing alfalfa hay with basil and fennel straw on nutrient digestibilities and nutritive values for rabbits at 10 weeks old

\begin{tabular}{|c|c|c|c|c|c|c|c|c|c|}
\hline \multirow{3}{*}{ Item } & \multirow[b]{3}{*}{ cono } & \multicolumn{6}{|c|}{ Replacement level } & \multirow{3}{*}{ SEM } & \multirow{3}{*}{ P-value } \\
\hline & & \multicolumn{3}{|c|}{ Basil straw } & \multicolumn{3}{|c|}{ Fennel straw } & & \\
\hline & & B25 & B50 & B75 & F25 & F50 & F75 & & \\
\hline \multicolumn{10}{|c|}{ A-Nutrients digestibility Coefficients: } \\
\hline DM & $60.01^{\mathrm{e}}$ & $63.56^{c}$ & $71.32^{\mathrm{a}}$ & $65.11^{\mathrm{b}}$ & $60.99^{d}$ & $59.53^{f}$ & $57.28^{g}$ & 0.18 & $<0.0001$ \\
\hline OM & $62.20^{\mathrm{e}}$ & $65.80^{c}$ & $72.68^{\mathrm{a}}$ & $66.83^{\mathrm{b}}$ & $63.96^{d}$ & $62.24^{\mathrm{e}}$ & $59.67^{f}$ & 0.16 & $<0.0001$ \\
\hline $\mathrm{CP}$ & $69.44^{\mathrm{C}}$ & $72.41^{\mathrm{cb}}$ & $79.98^{a}$ & $75.243^{b}$ & $71.97^{\mathrm{cb}}$ & $72.39 \mathrm{cb}$ & $68.58^{c}$ & 1.31 & 0.0005 \\
\hline EE & $74.90 e$ & $83.08^{\mathrm{dc}}$ & $88.03^{a}$ & $87.38^{\mathrm{ba}}$ & $81.16^{d}$ & $81.78^{d}$ & $85.02^{b c}$ & 0.85 & $<0.0001$ \\
\hline NFE & $73.62^{b}$ & $72.60^{\mathrm{cb}}$ & $81.37^{a}$ & $74.33^{b}$ & $69.26^{\mathrm{cd}}$ & $67.08^{\mathrm{ed}}$ & $65.10^{\mathrm{e}}$ & 1.22 & $<0.0001$ \\
\hline NDF & $29.45^{\mathrm{c}}$ & $37.67^{\text {ba }}$ & $44.85^{a}$ & $40.32^{\mathrm{ba}}$ & $33.49^{b c}$ & $33.39^{b c}$ & $33.64^{\mathrm{bc}}$ & 2.42 & 0.0091 \\
\hline ADF & $25.75^{\mathrm{a}}$ & $23.17^{\text {ba }}$ & $31.68 \mathrm{a}$ & $24.85^{\mathrm{ba}}$ & $30.22^{a}$ & $14.61^{b}$ & $20.98^{\text {ba }}$ & 3.17 & 0.0316 \\
\hline Hemicellulose & 48.85 & 65.75 & 48.93 & 73.01 & 53.46 & 71.27 & 59.67 & 5.92 & 0.2297 \\
\hline celluloses & $31.56^{b c}$ & $27.27^{c}$ & $47.55^{a}$ & $32.58^{b c}$ & $42.34^{\mathrm{ba}}$ & $23.08^{c}$ & $28.07^{c}$ & 2.70 & 0.0040 \\
\hline \multicolumn{10}{|c|}{ B-Nutritive values: } \\
\hline DCP & $13.46^{b}$ & $14.01^{b}$ & $15.73^{a}$ & $13.46^{b}$ & $13.87^{b}$ & $14.02^{b}$ & $13.73^{b}$ & 0.25 & 0.0003 \\
\hline TDN & $60.55^{b}$ & $63.32^{\mathrm{b}}$ & $69.60^{a}$ & $65.01^{b}$ & $61.57^{c}$ & $59.91^{b}$ & $57.76^{e}$ & 0.153 & $<0.0001$ \\
\hline
\end{tabular}

Mean within the same row with different superscripts are significantly different $(p \leq 0.05)$ Non fibrous carbohydrates (NFC) were calculated according to (Calsamiglia et al. 1995) using the following equation: NFC $=100-\{C P+E E+A s h+N D F\}$. Hemicellulose $=$ NDF - ADF. Cellulose $=$ ADF - ADL .

The total digestible nutrients (TDN) were calculated according to the classic formula (Cheeke et al 1982). 


\subsection{Plasma analysis variables}

The data of Table (6) showed the effect of replacing alfalfa hay with ascending levels of basil and fennel straw of growing rabbits on blood plasma constitutes. The data showed that, blood plasma total proteins, albumin and globulin $(\mathrm{g} / \mathrm{dl})$ for all dietary treatments are lies within the normal range reported by Melby and Altman (1974). There were no significant differences among all experimental treatments in blood plasma total proteins, albumin, ALT and AST. This result may be due to that all experimental diet was approximately iso caloric, iso-nitrogenous and iso-fibrous (Table 3 ). In this connection, Kumar et al (1980) postulated that blood total plasma protein concentration reflects the nutritional status of the animal and reported a positive correlation between blood total protein concentration and dietary protein level. Also, Bush (1991) reported a positive correlation between dietary protein and plasma protein concentration. Also, the same author stated that the low level of plasma proteins may be attributed to a decrease in the protein absorbed and synthesized and an increase in protein losses. In consist of the present results, Abdel-Azeem et al (2010) found that total protein concentration was not significantly affected by replacing clover hay with different levels of fennel straw in growing rabbit diets.

The data of Table (6) clearly showed that there were no significant differences among all experimental treatments in cholesterol $(\mathrm{mg} / \mathrm{dl})$. Also, Abdel-Azeem et al (2010) found that cholesterol concentration was not significantly affected by replacing clover hay with fennel straw in growing rabbit diets.

The data of Table (6) pointed that replacement alfalfa hay with 50 and $75 \%$ basil straw (diets B50 and $B 75$ ) resulted in decreased blood urea concentration compared with all experimental treatments, while replacement alfalfa hay with $25 \%$ basil straw and 25, 50 and 75 fennel straw (B25, F25, F50, and F75 diets) not significantly affect urea concentration.

The data of alkaline phosphatase activity (ALP) (U/L) (Table 6) clearly showed significant differences between rabbit groups received B75 and F50 diets and those rabbit group consumed F75 diet, while no significant differences were recorded among the rabbits received con0, B25, B75, F25, and $\mathrm{F} 5$ diets.

The data of Table (6) clearly showed that the rabbits received $\mathrm{B} 50$ and $\mathrm{F} 75$ diets recorded significantly lower creatinine concentration compared to the other experimental treatments. Creatinine concentration for animals received Con0, B25, B75, F25 and F50 showed insignificant differences. Özkanel et al (2012) showed that no statistically significant difference for creatinine between male and female animals. Abou Sekken et al (2008) reported that rabbit feeding $36 \%$ mixture of fennel hay and marjoram hay recorded the highest values of plasma total protein and globulin compared to other treatments. They also found significantly decreased in values of plasma cholesterol, AST and ALT when the clover hay is replaced by $\mathrm{FNH}$ in rabbit diets.

\subsection{Live body weight, daily weight gain and feed conversion ratio (FCR)}

The data of body weight changes and body weight gain are presented in Table (7). The data showed that, insignificant differences were observed in live body weight at 5 weeks of age (beginning time of the fattening experiment). During the first period ( 3 weeks after weaning) as well as during the entire of the experimental period (5-11 weeks of age), it could be observed that rabbits fed on diets containing (B25, B50, and B75) and fennel straw as a replacer for alfalfa hay as the main source of fiber, grew convergent with the control group. While insignificant effects were observed in live body weight at 5,8 and 11 weeks of age.

Concerning to body weight gain in the first period (5-8 weeks of age) the results showed that replacement of alfalfa hay with $25 \%$ fennel straw (F25) significantly reduced average daily gain compared with the other experimental treatments (Table 7), while no significant difference was observed among the other experimental treatments. On the contrary, the animals fed diets contained $25 \%$ fennel straw (F25) gave significantly higher average body weight gain compared with the other experimental groups and no significant differences were observed among the other experimental treatments. Regarding body weight gain during the total period from 5 to 11 weeks of age, the result indicates that no significant differences among all treatments were detected. This may be due to the similar values of nutrients digestibility for the groups received B25, B50, B75 and F25, F50, F75 compared to the con0 group (Table 3), parallel to the insignificant differences observed in DFC. In this connection, AbdelAzeem et al (2010) indicated that growing rabbits fed on a diet containing fennel straw replaced clover hay up to $33.33 \%$, had insignificantly higher live body weight. 

straws in growing rabbit dicts

Table 6. Effect of graded substitution of alfalfa hay with basil and fennel straw on plasma analysis of rabbits aged 11 weeks

\begin{tabular}{|c|c|c|c|c|c|c|c|c|c|}
\hline \multirow{3}{*}{ Item } & \multicolumn{7}{|c|}{ Replacement level } & \multirow{3}{*}{ 土SEM } & \multirow{3}{*}{$\begin{array}{l}p- \\
\text { value }\end{array}$} \\
\hline & \multirow{2}{*}{ Cono } & \multicolumn{3}{|c|}{ Basil straw } & \multicolumn{3}{|c|}{ Fennel straw } & & \\
\hline & & B25 & B50 & B75 & F25 & F50 & F75 & & \\
\hline $\begin{array}{ll}\text { Total proteins } \\
(\mathrm{g} / \mathrm{dl})\end{array}$ & 6.9 & 6.88 & 6.68 & 6.34 & 6.48 & 6.64 & 6.48 & 0.20 & 0.39 \\
\hline Albumin(g/dl) & 4.7 & 4.94 & 4.48 & 4.62 & 4.8 & 4.77 & 4.78 & 0.10 & 0.11 \\
\hline Globulin(g/dl) & 2.18 & 1.94 & 2.2 & 1.81 & 2.18 & 1.66 & 1.865 & & \\
\hline $\mathrm{A} / \mathrm{G}$ ratio & 2.17 & 2.55 & 2.04 & 2.55 & 2.17 & 2.90 & 2.56 & & \\
\hline $\begin{array}{l}\text { Cholesterol } \\
(\mathrm{mg} / \mathrm{dl})\end{array}$ & $47.12^{a}$ & 53.62 & 57.44 & 53.98 & 47.1 & 60.2 & 53.26 & 6.37 & 0.80 \\
\hline $\begin{array}{l}\text { Triglycerides } \\
(\mathrm{mg} / \mathrm{dl})\end{array}$ & $40.84^{b}$ & $63.66^{b}$ & $58.86^{b}$ & $44.16^{b}$ & $40.84^{a}$ & $110.96^{\mathrm{ba}}$ & $77.26^{\text {ba }}$ & 12.88 & 0.01 \\
\hline $\begin{array}{l}\text { Creatinine } \\
(\mathrm{mg} / \mathrm{dl})\end{array}$ & $0.68^{a}$ & $0.64^{a}$ & $0.46^{b}$ & $0.58^{a}$ & $0.58^{a}$ & $0.58^{a}$ & $0.46^{b}$ & 0.03 & 0.001 \\
\hline AST(U/L) & 27.6 & 34.5 & 24.00 & 23.00 & 31.00 & 27.4 & 26.2 & 4.24 & 0.60 \\
\hline $\operatorname{ALT}(\mathrm{U} / \mathrm{L})$ & 30.8 & 32.75 & 25.00 & 24.2 & 35.00 & 28.00 & 27.00 & 4.28 & 0.53 \\
\hline Urea (mg/dl) & $23.48^{a}$ & $24.94^{a}$ & $13.48^{\mathrm{b}}$ & $10.98^{b}$ & $23.48^{a}$ & $23.88^{a}$ & $25.34^{a}$ & 2.95 & 0.004 \\
\hline $\operatorname{ALP}(\mathrm{U} / \mathrm{L})$ & $130.6^{\text {ba }}$ & $117.2^{\mathrm{bac}}$ & $105.2^{b c}$ & $144.8^{a}$ & $124^{\mathrm{bac}}$ & $142.2^{\mathrm{a}}$ & $93.6^{c}$ & 11.22 & 0.02 \\
\hline
\end{tabular}

Mean within the same row with different superscripts are significantly different $(p \leq 0.05)$

Table 7. Effect of replacing alfalfa hay with basil and fennel straw on growth performance variables of rabbits aged 5-11 weeks

\begin{tabular}{|c|c|c|c|c|c|c|c|c|c|}
\hline \multirow{3}{*}{ Items } & \multicolumn{7}{|c|}{ Replacement level } & \multirow{3}{*}{ \pm SEM } & \multirow{3}{*}{$p$-value } \\
\hline & \multirow{2}{*}{ Cono } & \multicolumn{3}{|c|}{ Basil straw } & \multicolumn{3}{|c|}{ Fennel straw } & & \\
\hline & & B25 & B50 & B75 & F25 & F50 & F75 & & \\
\hline \multicolumn{10}{|c|}{ Live body weight (g) at: } \\
\hline 5 weeks & 625.00 & 631.43 & 625.00 & 622.78 & 637.50 & 612.78 & 623.50 & 18.25 & 0.98 \\
\hline 8 weeks & 1345.6 & 1291.70 & 1242.50 & 1235.00 & 1123.10 & 1240.70 & 1234.00 & 66.04 & 0.52 \\
\hline 11 weeks & $2050.56^{a}$ & 2065.00 & $2002.50^{a}$ & $2008.33^{a}$ & $2037.50^{\mathrm{a}}$ & $2043.33^{a}$ & $1855.00^{\mathrm{a}}$ & 67.72 & 0.40 \\
\hline \multicolumn{10}{|c|}{ Daily weight gain(g) from: } \\
\hline 5 to 8 weeks & 34.31 & 31.44 & 29.40 & 29.15 & 23.13 & 29.90 & 29.07 & 2.92 & 0.37 \\
\hline 8 to 11 weeks & $33.57^{b}$ & $36.82^{\text {ba }}$ & $36.19^{\text {ba }}$ & $36.83^{\text {ba }}$ & $43.54^{\mathrm{a}}$ & $38.22^{\text {ba }}$ & $29.57^{b}$ & 2.48 & 0.02 \\
\hline 5 to 11 weeks & 33.94 & 34.13 & 32.798 & 32.99 & 33.33 & 34.06 & 29.32 & 1.02 & 0.34 \\
\hline \multicolumn{10}{|c|}{ Feed conversion ratio (FCR) from } \\
\hline 5 to 8 weeks & 2.41 & 2.45 & 2.25 & 2.31 & 4.6623 & 2.55 & 2.54 & 0.65 & 0.37 \\
\hline 8 to 11 weeks & $3.48^{\mathrm{ba}}$ & $3.06^{b}$ & $3.53^{\text {ba }}$ & $3.62^{\mathrm{ba}}$ & $2.78^{b}$ & $3.74^{\text {ba }}$ & $4.71^{\mathrm{a}}$ & 0.44 & 0.02 \\
\hline 5 to 11 weeks & $2.79^{b}$ & $2.58^{\mathrm{b}}$ & $2.75^{\mathrm{b}}$ & $2.99^{\text {ba }}$ & $2.89^{\mathrm{ab}}$ & 2.82 & 3.33 & 0.05 & 0.34 \\
\hline Mortality rate & 4 & 2 & 4 & 1 & 1 & 1 & 1 & & \\
\hline
\end{tabular}

Mean within the same row with different superscripts are significantly different $(p \leq 0.05)$. 
Regarding the feed conversion ratio (FC) the data presented in Table (7) showed that during the first period from 5 to 8 weeks of age, the best FCR was observed for rabbits fed B50 diet. On the other hand, the result showed no significant differences among all experimental treatments. During the second period from 8 to 11 weeks of age, the best FCR was observed for rabbits fed F25 diet. While the worst ratio was recorded for those fed F75. During the total period from 5 to 11 weeks of age, the best FCR was observed for rabbits fed B25 followed by $\mathrm{B} 50$ and control, where the worst ratio is was recorded for those fed F75. On the other hand, the results showed that significant differences between F75 from side and B25 and B50 from the other side while no significant differences between F25, F50, F75, B75 and con0. Furthermore, Radwen and Khailil (2002) found that the best FCR (feed/gain) $3.76 \mathrm{~kg}$ feed $/ \mathrm{kg}$ gain was recorded by rabbits fed 34 and $50 \%$ fennel by-product, while the poorest one 4.16 and 4.08 were achieved by rabbits fed 0 and $17 \% \mathrm{FNH}$ levels. Also, they found that feed intake of rabbits received diets containing different levels of FNH was not significantly different. Abd ElAzeem et al (2010) showed that rabbits fed on diet containing $\mathrm{FNH}$ replaced clover hay up to $33.33 \%$, were insignificantly higher live body weight and body weight gain and significantly $(p<0.05)$ higher daily feed consumption compared with the other experimental diets. Values of FCR showed not significant differences within all tested groups. While, Trebusak et al (2011) showed that there were on significant differences in the final body weight.

The data presented in Table (7) showed that replacing alfalfa hay with B25, B75, F25, F50 and F75 decreased mortality rate compared to con 0 . This may be due to effect of the residual of essential oil in Basil and fennel straw which may be have a positive effect on rabbit's health and viability. Omer et al (2013) concluded that adding $0.5 \%$ fennel seeds with $0.5 \%$ oregano leaves as feed additives to rabbit diets contained $2 \%$ oil improved daily gain; both nutrient digestibility coefficients and nutritive values as well as realized the highest value of relative economic efficiency and lowered value of feed cost/ $\mathrm{kg}$ live body weight.

\subsection{Carcass traits}

The data of Table (8) clearly showed no significant effects $(p>0.05)$ were detected in absolute or relative weights for most of the carcass traits due to feeding diets containing different basil and fennel straw levels. Rabbit groups the received a B50 diet were recorded higher dressing percentage, kidney weight, liver weight and spleen weight followed by the group received $\mathrm{F} 50$ diet than all treatments. Rabbits fed B 25 diet had the weights of the hot carcass, and head weight and heart weight than the B50 diet. On the other hand, Abdel-Azeem et al (2010) recorded that higher dressing and hot carcass weight percentages were recorded with growing rabbits fed fennel straw, but carcass fat (\%) was not significantly decreased by using fennel straw levels. Radwan and Khalil (2002) found that dressing percentage, liver, and heart, as a percent to the body weight of rabbits fed FNH diets insignificantly improved with raising $\mathrm{FNH}$ levels. While Abou Sekken et al (2008) observed that a group fed a diet containing $54 \% \mathrm{FNH}$ and marjoram hay mixture achieved significantly $(\mathrm{P}<0.05)$ higher carcass, dressing percentage, edible giblets percentage than the control group.

\subsection{Economic efficiency (EEF)}

The data of Table (9) showed that the increase in replacement level of alfalfa with basil or fennel straws caused a gradual decrease in $\mathrm{kg}$ feed cost, due to the low cost of basil straw and fennel straw (1500 L.E/ton) compared to the cost of alfalfa hay which is (3200 L.E/ton). Replacing alfalfa hay with $(25,50,75 \%)$ for either basil hay or fennel hay caused a gradual decrease in total feed cost, while the inclusion of B75 slightly decreased feed cost as a result to increasing daily feed consumption for this group. Values of economic efficiency, relative economic efficiency and performance index were improved with partial replacement of alfalfa hay by basil hay and fennel hay in the growing rabbit diets. The present results show that, EEF, and REEF of the rabbits were highest with $\mathrm{B} 25$ and $\mathrm{F} 50$ being (119.10 and104.67), respectively. Abdel-Azeem et al (2010) found that, rabbits fed $21.0 \% \mathrm{FNH}$ (a diet containing $\mathrm{FNH}$ replaced clover hay up to $66.66 \%$ gave the highest economic efficiency percentage. 

straws in growing rabbit dicts

Table 8. Effect of replacing alfalfa hay with basil and fennel straw on carcass traits of rabbits aged 11 weeks

\begin{tabular}{|c|c|c|c|c|c|c|c|c|c|}
\hline \multirow{3}{*}{ Item } & \multicolumn{7}{|c|}{ Replacement level } & \multirow{3}{*}{ 土SEM } & \multirow{3}{*}{$\begin{array}{c}p- \\
\text { value }\end{array}$} \\
\hline & \multirow{2}{*}{ Con 0} & \multicolumn{3}{|c|}{ Basil straw } & \multicolumn{3}{|c|}{ Fennel straw } & & \\
\hline & & B25 & B50 & B75 & B25 & B50 & B75 & & \\
\hline Dressed weight (g) & 1225.26 & 1274.43 & 1278.58 & 1234.94 & 1237.56 & 1233.67 & 1137.61 & 66.92 & 0.42 \\
\hline Dressing percentage & 61.07 & 61.68 & 63.67 & 61.12 & 60.75 & 60.42 & 58.15 & & \\
\hline Hot carcass $(\mathrm{g})$ & $1058.75^{a}$ & $1102.85^{a}$ & $1084^{a}$ & $1065.62^{a}$ & $1053.8^{a}$ & $1042.9^{a}$ & $906^{a}$ & 40.98 & 0.05 \\
\hline 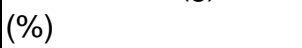 & 52.77 & 53.33 & 54.13 & 52.70 & 51.72 & 51.04 & 48.84 & & \\
\hline Head weight (g) & $97.25^{\mathrm{ab}}$ & $101.43^{a}$ & $100^{a}$ & $100^{\mathrm{a}}$ & $98.75^{\mathrm{ab}}$ & $101.11^{\mathrm{a}}$ & $89^{b}$ & 3.03 & 0.10 \\
\hline (\%) & 4.85 & 4.91 & 4.99 & 4.99 & 4.85 & 4.95 & 4.80 & & \\
\hline Heart weight (g) & $6.87^{\mathrm{ba}}$ & $7.64^{\mathrm{a}}$ & $7.08^{\mathrm{ba}}$ & $6.50^{\mathrm{ba}}$ & $6.75^{\text {ba }}$ & $7.00^{\mathrm{ba}}$ & $6.25^{\mathrm{b}}$ & 0.34 & 0.21 \\
\hline 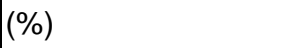 & 0.65 & 0.69 & 0.65 & 0.61 & 0.64 & 0.67 & 0.69 & & \\
\hline Heart fat (g) & $0.75^{a}$ & $1.14^{\mathrm{a}}$ & $0.91^{\mathrm{a}}$ & $1.06^{\mathrm{a}}$ & $1.12^{\mathrm{a}}$ & $1.16^{\mathrm{a}}$ & $0.75^{a}$ & 0.19 & 0.44 \\
\hline$\%$ & 0.1 & 0.1 & 0.1 & 0.1 & 0.1 & 0.1 & 0.1 & & \\
\hline Kidneys weight (g) & $10.87^{c}$ & $12.25^{b c}$ & $19.25^{a}$ & $14.31^{b c}$ & $14.5^{\mathrm{bc}}$ & $16 b^{a}$ & $13.3^{\mathrm{bc}}$ & 1.16 & 0.003 \\
\hline$\%$ & 1.03 & 1.11 & 1.78 & 1.34 & 1.38 & 1.53 & 1.47 & & \\
\hline Kidneys fat (g) & $11^{a}$ & $10.74^{\mathrm{a}}$ & $10.75^{a}$ & $9.37^{a}$ & $7.81^{a}$ & $14.27^{a}$ & $7.8^{a}$ & 2.11 & 0.44 \\
\hline$\%$ & 1.04 & 0.97 & 0.99 & 0.88 & 0.74 & 1.37 & 0.86 & & \\
\hline Liver weight (g) & $62.38^{b}$ & $62.5^{\mathrm{b}}$ & $87.5^{\mathrm{a}}$ & $62.81^{b}$ & $78.31^{\text {ba }}$ & $82.66^{\text {ba }}$ & $64.85^{b}$ & 6.03 & 0.03 \\
\hline$\%$ & 5.89 & 5.67 & 8.07 & 5.89 & 7.43 & 7.93 & 7.16 & & \\
\hline Spleen weight (g) & $1.75^{\mathrm{ba}}$ & $1.07^{c}$ & $2.17^{a}$ & $2^{\mathrm{a}}$ & $1.18^{\mathrm{bc}}$ & $1.38^{\mathrm{bc}}$ & $1.4^{\mathrm{bc}}$ & 0.16 & 0.001 \\
\hline$\%$ & 0.17 & 0.10 & 0.20 & 0.19 & 0.11 & 0.13 & 0.15 & & \\
\hline Cecum pH & $6.3^{a}$ & $6.06^{\mathrm{a}}$ & $5.99^{a}$ & $6.48^{a}$ & $6.14^{a}$ & $6.71^{a}$ & $6.03^{a}$ & 3.32 & 0.54 \\
\hline
\end{tabular}

Mean within the same row with different superscripts are significantly different $(p \leq 0.05)$.

Table 9. Economic traits of NZW rabbits aged 11 weeks as affected by dietary replacement of alfalfa hay with basil straw and fennel straw

\begin{tabular}{|c|c|c|c|c|c|c|c|c|c|}
\hline \multirow{3}{*}{ Item } & \multicolumn{7}{|c|}{ Replacement level } & \multirow{3}{*}{ ISEM } & \multirow{3}{*}{$\begin{array}{c}\mathrm{p}- \\
\text { value }\end{array}$} \\
\hline & \multirow{2}{*}{ Cono } & \multicolumn{3}{|c|}{ Basil straw } & \multicolumn{3}{|c|}{ Fennel straw } & & \\
\hline & & B25 & B50 & B75 & F25 & F50 & F75 & & \\
\hline Total Fl/rabbit Kg & 3.89 & 3.67 & 3.72 & 4.11 & 3.98 & 3.87 & 3.97 & & \\
\hline price /kg FI (L.E) & 5.17 & 5.09 & 4.99 & 4.86 & 5.07 & 5.00 & 4.87 & & \\
\hline feed cost/rabbit (L.E) & 20.10 & 18.69 & 18.54 & 19.96 & 20.16 & 19.32 & 19.30 & & \\
\hline Total cost (L.E) +(a) & 80.10 & 78.69 & 78.54 & 79.96 & 80.16 & 79.32 & 79.30 & & \\
\hline Body weight (Kg) & 2.05 & 2.07 & 2.00 & 2.01 & 2.04 & 2.04 & 1.86 & & \\
\hline Cost /kg BW (L.E) & 39.06 & 38.10 & 39.23 & 39.82 & 39.35 & 38.83 & 42.75 & 1.49 & 0.4071 \\
\hline Total revenue (L.E) & 92.27 & 92.93 & 90.09 & 90.36 & 91.67 & 91.94 & 83.48 & 3.21 & 0.401 \\
\hline Net revenue (L.E) & 12.17 & 14.24 & 11.55 & 10.40 & 11.51 & 12.62 & 4.18 & 3.21 & 0.4396 \\
\hline Economic efficiency & 15.19 & 18.10 & 14.70 & 13.01 & 14.36 & 15.90 & 5.27 & 4.11 & 0.4354 \\
\hline Relative Economical efficiency & 100.00 & 119.10 & 96.76 & 85.59 & 94.48 & 104.67 & 34.68 & & \\
\hline
\end{tabular}

(a) Including fixed cost (60 L.E/rabbit), (b) Assuming that the selling price \{is (45) L.E\}, Price /ton of basil straw or fennel straw $=1500$ L.E Price $/$ ton of alfalfa hay $=3200$ L.E. 


\section{CONCLUSION}

The results of this study revealed that basil and fennel straw can successfully replace up to $75 \%$ of alfalfa hay in NZ rabbit diets between 5 and 11 weeks of age, without adverse effects on their performance. It can be useful in reducing rabbit feed costs.

\section{REFERENCES}

Abo-Zeid N. 1988. Aromatic plants. Agricultural products and Drugs. El-Daar Arabic for publication and Distribution, Egypt, pp. 300-499. (In Arabic).

Abou Sekken M.S., Fahmy A.A. and Ahmed S.S. 2008. Performance of growing rabbits fed diet containing different levels of Fennel and Marjoram wastes under desert environmental conditions. Egypt. J. Nutrition and Feeds, 11(1), 1-23.

Abdel-Azeem F., El-Sanhoury M.H., El-Hommosany Y.M. and Abd El-Sattar M. 2010. Efficiency of using fennel hay in feeding growing rabbits. The $6^{\text {th }}$ Inter. Con. on Rabbit Prod. in Hot Clim., Assuit, Egypt, pp. 139- 150.

A.O.A.C. 2002. Official methods of analysis. Association of Official Analytical Chemists, Washington, D.C. Chapter 4, pp. 1-52.

Armstronge W.D. and Carr C.W. 1964. Physiological Chemistry: Laboratory Directions, $3^{\text {rd }}$ ed. Bures Publishing Co. Minneapolis, Minnesota, USA, $75 \mathrm{p}$.

Agriculture Economic 2005. Central administration, Agriculture Economic. Area yield and production of Medical Aromatic and flower plant. Economic Affairs sector, Ministry of Agric., ARE, pp. 1-23.

Bush B.M. 1991. Interpretation of laboratory results for small animal clinicians. Oxford Blackwell scientific publications, London, $\mathbf{5 1 5} \mathbf{p}$.

Cheeke P.R. 1987. Rabbit Feeding and Nutrition. Academic press, New York, USA, pp. 295-301.

Cheeke P.R., Patton N.M. and Tempelton G.S. 1982. Rabbit production. 5th Edition, Interstate Printers and Publishers Danville II., USA, 65 p.

Colin M., Arkurst G. and Lebas F. 1973. Effect of addition of methionine to the diets of growth of the rabbit. Annals de Zooteches, 22(4), 485491.

Doumas B.T., Waston W.A. and Biggs H.G. 1971. Determination of serum albumin. J. Chem. Acta., 31, 87-89.
Duncan D.B. 1955. Multiple range and multiple $F$ test. Biometrics, 11, 1-42.

Eadie J.M., Hobsen P.N. and Mann S.O. 1967. A not on some comparisons between the rumen content of barley fed steers and that of young calves also fed on high concentrate ration. J. Anim. Production. 9, 247-250.

El-Tahan A.A.H., El- Gendy K.M., Abd El-Rahman G. and Etman K.E.L. 2003. The effect of replacing maize silage with peanut tops silage on performance of lambs. Egypt. J. Nutr. Feeds, 6 (special issue), 1367-1379.

Fekete S. and Gippert T. 1986. Digestibility and nutritive value of nineteen important feedstuffs for rabbits. J. Appl. Rabbit Res., 9(3), 103-108.

Fawcett J.K. and Soctt J.E. 1960. A rapid and precise method for the determination of urea. J. Clin. Path., 13, 156-159.

Greiling H. and Gressner A.M. 1995. Lehrbuch der Klinischen Chemieund Pathobiochemie. $3^{\text {rd }}$ Stuttgart, New York: Schattauer Verlag. pp. 223-224, 749-750.

Husdan H. 1968. Chemical determination of creatinine with depproteinization. Clin. Chem., 14, 222.

Ibrahim A.M., El-Ghamry A.A. and EI-Mallah G.M. 2000. Effect growth and metabolic changes of rabbits. Egyptian J. Rabbit Sci., 10(1), 105120.

Kumar N., Singh U.B. and Verma D.N. 1980. Effect of different levels of dietary protein and energy on growth of male buffalo cavles. Indian J. Sci. 51, 513-519.

Melby E.C.Jr. and Altman N.H. 1974. CRC handlook of laboratory animal Sci., Vol. CRC Press, Cleveland, Ohio, pp. 1-451.

NRC 1977. National Research Council, Nutrient Requirements of Rabbits. 2nd Rev. ed. National Academy of Sci., Washington, DC., USA, pp. 135.

North M.O. 1981. (Cited by Abdel-Azeem. F. and El-Bordeny N.E. 2007. Utilization of palmtree leaves in feeding growing rabbit. Egyptian J. of Nutrition and Feeds, 10(2), 275-288.

Omer H.A.A., EL-Nomeary Y.A.A., EL-Kady R.I., Badr M.M. Azza, Ali F.A.F., Ahmed M. Sawsan, ELAllawy H.M.H. and Ibrahim. Sh. A.M. 2013. Improving the Utilization of Rabbit Diets Containing Vegetable Oil by Using Fennel (Foeniculum vulgare) and Oregano (Origanum vulgare L.) as Feed Additives. Life Sci. J. 2013; 10(1), 2625-2636] (ISSN: 1097-8135). http://www.lifesciencesite.com. 307 
Pisani T., Gebski C.P. and Leary E.T. 1995. Accurate direct determination of Low-density Lipoprotion, Cholesterol Assay. Arch Pathol. Lab Med, 119, 1127.

Özkan C., Kaya A. and Akgül Y. 2012. Normal values of hematological and some biochemical parameters in serum and urine of New Zealand white Rabbits. World Rabbit Sci., 20, 253-259.

Radwan M.S.M. and Khalil E.F. 2002. Nutritional evaluation of Fennel hay inclusion in rabbit diets. Egyptian J. Rabbit Sci., 12(1), 85-94.

Reitman S. and Frankel S. 1957. A calorimetric method for the determination of serum glutamic oxalactic and glutamic pyruvic transaminase. Am. J. Clin. Path., 28, 56-63.
SAS 2002. Statistical Analysis System guide: Version $8.2^{\text {th }}$. Institute Inc.Cary. NC. USA.

Szumacher-Strabel M., Potkan 'ski A, Kowalczyk J., Cies 'lak A., Czauderna M., Gubał a A, Jedroszkowiak P. 2002. The influence of supplemental fat on rumen volatile fatty acidprofile, ammonia and $\mathrm{pH}$ levels in sheep fed a standard diet. J. Amin, Feed Sci. 11, 577-587.

Trebusak T., Levart A., Voljc M., Tomazin U. and Pirman T. 2011. The effect of linseed oil supplementation on performance fatty acid composition and oxidative status of rabbits. Acta Agric. Solvenica, 98(2), 119-125.

Van Soest P.J., Robertson J.B. and Lewis B.A. 1991. Methods for dietary fiber, neutral detergent fiber and non -starch polysaccharides in relation to animal nutrition. J. Dairy Sci. 74, 3583-3597. 


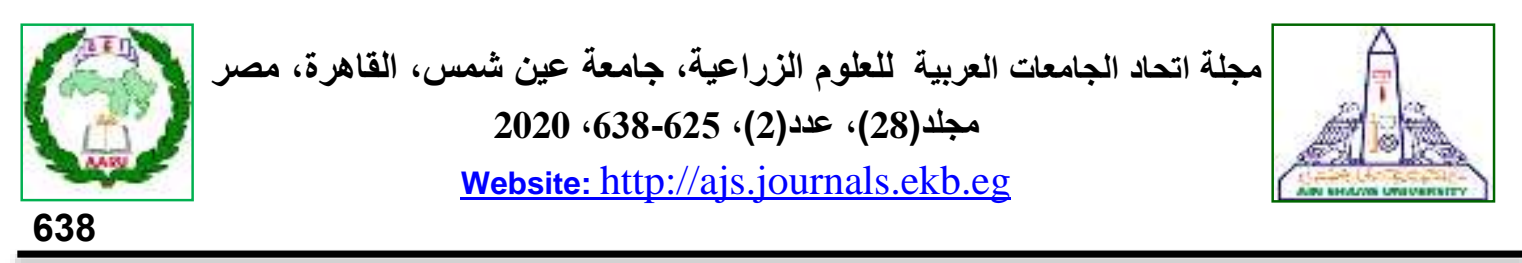

$$
\begin{aligned}
& \text { تأثير إستبدال دريس برسيم الحجازي بمستويات متدرجه من أتبان الشمر والريحان } \\
& \text { فى علائق الأرانب النامية } \\
& \text { هيام السيد دراز 1" - فتحي عبد العظيم } 2 \text { - أسامة أحمد البحيرى3 } \\
& 4 \text { ثناء فؤاد محمدى } 1 \text { - نصر البرديني } 4
\end{aligned}
$$

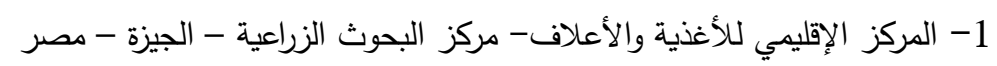

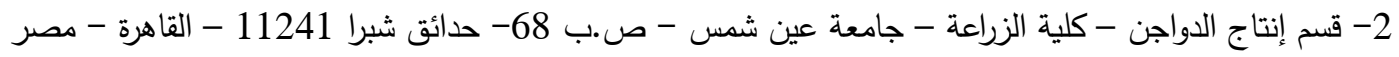

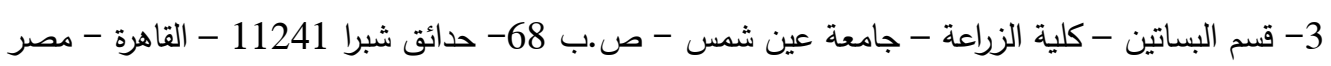

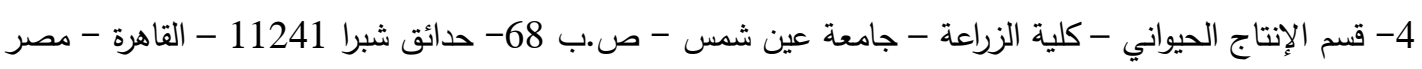

*Corresponding author: Hayamderaz@yahoo.com

Received 1 March, 2020

Accepted 28 July, 2020

والمادة العضوية والبروتين الخام والمستخلص الاثير

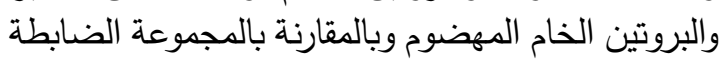

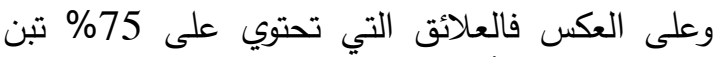

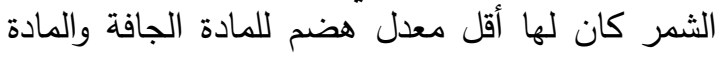

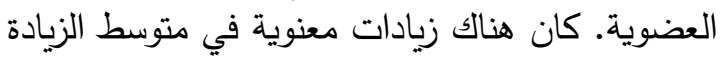

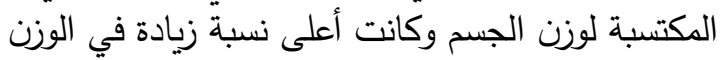

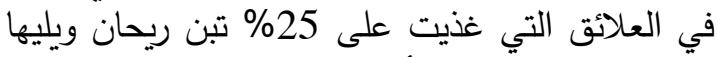

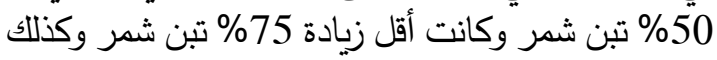

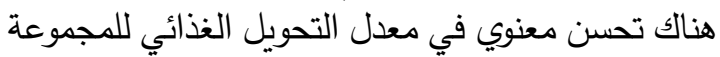

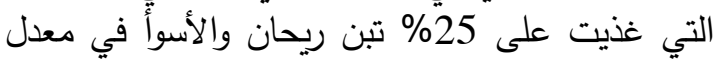

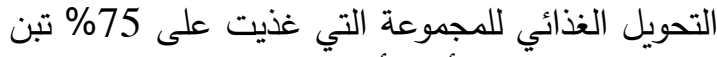
الثمر. لم يلاحظ أي تأثير "معنوي لاستبدال دريس عليس

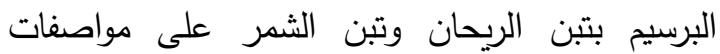
وخصائص الذبيحة فيما عدا وزن القلب والبن والكلى والكبد

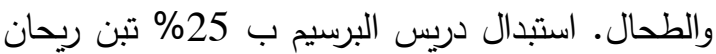
و50\% تبن شمر أدى الى تقليل تكلفة التغذية، بينما

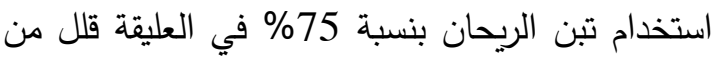
تكلفة التغذية وذللك نتيجة زيادة الاستهلانك اليومي. الكلمات المفتاحية: تبن الثمر، تبن الريحان، الأرنب،

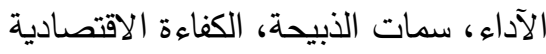

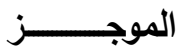

يحتوي تبن الثمر وتبن الريحان على نسبة مرتفعة

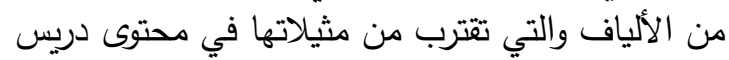

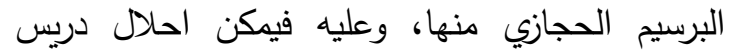
البرسيم الحجازي بتبن الثمر وتبن الريحاني وليحان في أعلاف

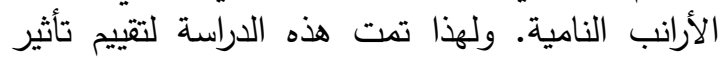

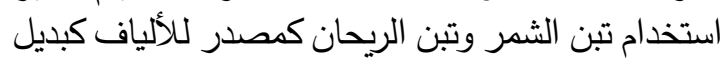
للدريس في علائق الأرانب النامية. تم استخدام عدد التبن 84

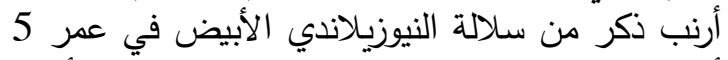

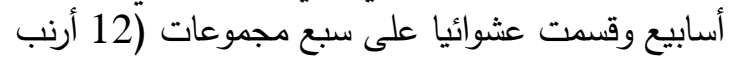
لكل مجموعة). تم تركيب وإعداد سبع علائق علئق تجريبية

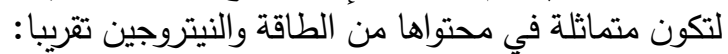

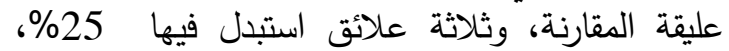

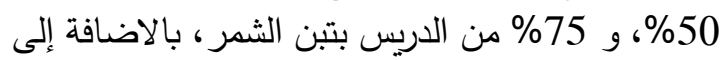

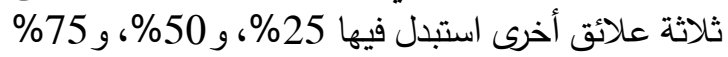

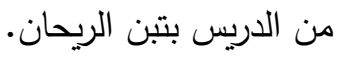

$$
\text { وكانت أهم النتائج المتحصل عليها كما يلي }
$$

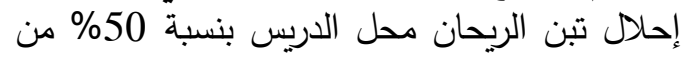
الدريس ادى الى تحسن في معاملات هضم المادة الجافة 